\title{
Total Quality Management, Dynamic Capabilities, and Competitive Advantages: Mediating Effect of Innovation
}

\author{
Firman $^{1}$ and Gesit Thabrani ${ }^{2}$ \\ ${ }^{1}$ Dept. of Management, Faculty of Economics, Universitas Negeri Padang, Padang, Indonesia \\ $\square$ (e-mail) firmanfeunp@gmail.com \\ ${ }^{2}$ Dept. of Management, Faculty of Economics, Universitas Negeri Padang, Padang, Indonesia \\ $\triangle$ (e-mail) gesitthabrani@gmail.com
}

\begin{abstract}
This study aims to determine and analyze the effect of total quality management, dynamic capabilities, and innovation to competitive advantage. This study also tries to test whether innovation mediates the relationship between total quality management and dynamic capabilities to competitive advantage. This type of research is causative research. population in this research is all leadership of study program at the college that's existing in Padang. The type of data used is the primary data from the department or program leadership. Questionnaires were sent to 90 respondents and 50 respondents who returned the questionnaire. The results show that dynamic capabilities and innovations have a positive and significant impact on the competitive advantage. This study fails to prove that innovation as a variable mediating the relationship between total quality management, dynamic capabilities to competitive advantage.
\end{abstract}

Keyword: total quality management, dynamic capabilities, innovation, and competitive advantage

\section{Introduction}

Globalization era, free market, and technological enhancement make the competition so high that every company and organization strives to have the competitive advantage in order to survive the rapid change of environment in the long term. Creating and improving competitive advantage has become one of the main focus and challenges in business and economics (Breznik \& Hisrich, 2014). Therefore, the company's business model should consider long-term sustainability by taking into consideration the company's relationship to the environment and the ethical values applicable to that environment(Q. Wu, He, \& Duan, 2013).

The terms competitiveness and other theories related to competitive advantage not only grow in business firms but also in the public sector because they share the phenomenon of competition, location and the need to adapt and innovate according to consumer needs and environmental change(Haan, 2015). Increasing the need for an educated and skilled workforce to make educational institutions become increasingly in demand by the community which is accompanied by increasing opportunities and opportunities for people to continue higher education. the company's competitive advantage will determine the position of the industry company to produce long-term sustainability and durability in a long-term manner by increasing satisfaction with consumers and other stakeholders (Kafetzopoulos \& Gkana, 2015).

An organization builds a commanding advantage based on internal resources and leverages the external environment to produce power that is difficult for other companies to imitate in such a short time. According to Deming, competitive advantage can be built by improving quality because it can reduce costs and improve customer satisfaction making it more efficient than other companies(Shenawy, Baker, \& Lemak, 2007). The ability of the company to provide excellent servants to customers demonstrates the success of service providers to empower their resources to satisfy the needs and wants of consumers (Kuo, Lin, \& Lu, 2017). 
In addition, companies must also have the ability to adapt to the needs and changes in the external environment known as dynamic capabilities. Dynamic capability is the company's ability to adapt to changing environments by altering a set of resources owned by the company. Such upgrades arise because of understanding and exploiting opportunities and threats, multiplying opportunities and improving, combining, protecting, and reconfiguring tangible and intangible assets (Kuo et al., 2017).

This rapidly changing consumer and external environment makes quality and innovation practices have an important role in the company to have a competitive advantage and to survive in the long term (Kafetzopoulos \& Gkana, 2015). Total quality management and innovation have the same goal, especially in service companies, which is to unify the purpose and function of the company to satisfy the consumers and improve the company's competitive advantage by optimizing the role of employees in the management and business process (Bon \& Mustafa, 2013). The ability of corporate innovation is the result of a continuous learning process that generates new products, processes, and systems that generate profits for the company(Breznik \& Hisrich, 2014).

To accommodate the interests and needs of this higher education institution, in Indonesia today, as of April 2017, there are 4,498 public and private universities supported by 268,292 lecturers (http://forlap.dikti.go.id). Coupled with the opening of opportunities and opportunities to continue higher education abroad or vice versa, the universities in Indonesia are expected to have the competitive advantage in order to improve its performance at the national and international levels.

Padang is the capital of West Sumatra Province and became the largest city in West Sumatra. As the provincial capital, many public facilities and public education institutions are available to serve the needs and interests of the community. Currently, there are three state universities (Universitas Negeri Padang, Universitas Andalas, and Universitas Islam Negeri Imam Bonjol), two state polytechnics (Politeknik Negeri Padang and Politeknik Kesehatan Kementerian Padang), and 1 state academy (Padang Industrial Technology Academy) and many other private higher education.

Based on the introduction, the researcher is interested to conduct research to analyze the effect of total quality management and dynamic capabilities to the competitive advantage of the existing universities in Padang. This study also wants to test the role of innovation as a variable mediating the influence between total quality management and dynamic capabilities with the advantage of competing universities in Padang.

\section{Competitive Advantage}

Competitive advantage is the implementation of strategies that cannot be applied directly by other companies that can affect cost reduction, increase market opportunities, reduce competition levels, so as to improve the performance of the company (Kuo et al., 2017). The concept of competitive advantage was introduced by Ansoff in 1965 and Uyterhoeven et al. in 1973, which defines it as a way for companies to use their capabilities and resources to generate superior returns in competitive markets, and specifically in the business sector popularized by Michael Porter in the 1985 (Haan, 2015).

Competitive strategy plays an important role to improve the company's performance and produce competitive advantages consisting of differentiation, cost, and focus (Porter, 2008). With the right competitive strategy, the company can build relationships with suppliers and customers, influence customer purchasing decisions, and generate uniqueness so that companies have opportunities to enter new markets, increase value-added, create new products, and improve enterprise efficiency (Ashrafi \& Mueller, 2015). Competitive advantage will result in a unique system for competitors because it produces sustainable value and efficiency gained by competing on differentiation or quality, competing on cost, and competing on responses (Heizer, Render, \& Munson, 2017).

Prior to building this competitive advantage, there are three important perspectives to be considered by companies, namely resources view, value-chain analysis and fife force model (Heizer et al., 2017). In the review of resources view, the company optimizes the availability of financial, 
physical, labor and technology and ensures the strategy used in accordance with the resources it has. Another perspective is value-chain analysis introduced by Porter that is useful for identifying activities that describe potential strength or strengths and opportunities to develop the competitive advantage. The company can provide unique value through product research, design, human resources, supply chain, innovation and Total Quality Management. Porter also provides another five-member perspective known as a force model that describes the power of peas consisting of direct competitors, potential new competitors, consumers, suppliers and substitution products.

\section{Total Quality Management}

Quality is one of the words that often appear in the study of operations management because it is one of the goals that must be achieved company. The notion of quality can vary depending on context and usefulness. Quality can be defined as all the features and characteristics of a product or service associated with its ability to satisfy visible or disguised needs (Heizer et al., 2017). Quality becomes one important factor in the production process because it can describe the ability of a good product or service in meeting the needs of consumers. In other words, quality can be defined as the suitability of consumer expectations with which they feel when consuming the product. Consumers today are more selective in choosing products and not just considering cheaper prices or products.

One of the company's philosophy in conducting operations is total quality management (TQM), also known as integrated quality management. TQM is a corporate management concept that strives to excel in every aspect of the company's operational processes starting from the initial supplier to the end user. One of the foundations in TQM is the desire of all parties or elements in the organization to make the continuous improvement (continuous improvement). The TQM definition is an integrated approach to obtaining and maintaining high-quality output, focusing on maintenance, continuous improvement, and prevention of failures at all levels and functions of the organization, in order to meet or exceed consumer expectations (Flynn, 1994).

\section{Dynamic Capabilities}

The concept of dynamic capabilities was first developed by Teece and Pisano in 1994 stating that in a dynamic corporate environment, the company's excellence will stop at internal processes and corporate routines that cause companies to difficulties updating and developing their products and processes to meet customer needs (Nielsen, 2006). Teece and Pisano further define dynamic capabilities as the company's ability to integrate, build and redesign internal and external corporate competencies to cope with rapidly changing and radical changes in the environment. With the existence of dynamic capabilities, the company is expected to develop and update the company's overall capability.

Dynamic capabilities are the company's potential to systematically solve problems by analyzing opportunities and threats, to make timely decisions, and to execute strategic decisions and changes efficiently to ensure correct direction ( $\mathrm{Li} \& \mathrm{Liu}, 2014$ ). Based on this definition, there are three components present in the dynamic capabilities: 1) Strategic sense-making capacity, which is the process for developing cognitive maps, for sensing and interpreting stimuli or altering within the framework of reference to search effectively for and analyzing information from the internal and external environment. 2) Timely decision-making, which is the time needed to formulate, evaluate and select a strategic orientation in order to adapt to changes in the environment in a timely manner. 3) Change implementation capacity, ie the ability to implement and coordinate strategic decisions and corporate change, involving various managerial and organizational processes, depending on the nature of the objectives and the specific tasks required

\section{Innovation}

According to Plessis, innovation is creating new ideas and knowledge that will generate new business output aimed at developing internal business processes and structures and to create products and services according to consumer needs (Al-Hakim \& Hassan, 2013). While Rogers 
explains that innovation is a change that occurs in companies that lead to relative profits, harmony, comprehensive, practical and can be observed so that innovation becomes a source of profit and competitiveness to improve company performance and reduce risk (Caniato, Caridi, \& Moretto, 2013). Since its introduction by Schumpeter in the 1930s, innovation has become one of the main focuses on researchers and practitioners for companies to adapt to dynamic environmental changes and high levels of competition in the industry (Breznik \& Hisrich, 2014).

Today innovation has been recognized as one of the key components to ensure the sustainable competitive advantage in the face of rapidly changing and radical environments in line with technological developments (Lee, Leong, Hew, \& Ooi, 2013). Lawson and Samson define innovation as the company's ability to transform knowledge and ideas into new products and goods, new technologies for new production processes, structures or administrative systems (Migdadi, Zaid, Zaidbauedujo, Yousif, \& Al-hyari, 2017). The range of innovations undertaken by this company can start from a genuinely new innovation to the most minimal development, and based on its novelty level can be in the form of development by changing technology, the least product or system, or in a breakthrough that has complexity and requires new knowledge and technology (Cheng \& Chen, 2013).

Zhao et al. in Bon and Mustafa (2013) classifies the types of innovations into three main groups: 1) Radical innovations that produce new products or processes that have not existed before vs. incremental innovations that develop pre-existing products. 2) Product innovation that is developing or creating a new product or service or developing a pre-existing vs. process innovation that develops the effectiveness and efficiency of the production process. 3) Technological innovation that is, applying technology to business processes or products vs. administrative innovation, is implementation of new ideas to develop processes, routines, structures or organizational systems.

\section{The influence of TQM on the Competitive advantage}

Deming explained that the goal of TQM implementation is to develop and maintain the competitive advantage by increasing efficiency through cost reduction and enhancing customer satisfaction, and Cummberl-Hunt adds that competitive advantage can be achieved by differentiating it from other companies through cost and differentiation advantages (Shenawy et al., 2007). Quality management practice is one of the important activities that will improve product quality, production process, efficiency, profit and corporate advantage so that the company is expected to focus more on designing strategies that guarantee the improvement of quality (Kafetzopoulos \& Gkana, 2015).

Previous research has been linked to quality management with two competitive strategies: superior in cost and differentiation, while innovation is derived only by differentiation strategy alone so that managing quality well will provide an opportunity for the company to offer products that match the needs of consumers, thus increasing consumer loyalty and becoming company advantage compared to competitors. With the improvement of the company's management orientation to improve the quality management practices, the company will operate efficiently and become a solid foundation to build another competitive advantage dimension $(\mathrm{Wu}, 2015)$. Based on the reference, the hypothesis 1 of this study is as follows:

$\mathrm{H}_{1} \mathrm{TQM}$ has a positive and significant impact on the competitive advantage

\section{The influence of Dynamic Capabilities on the Competitive Advantage}

Dynamic capabilities are a major consideration for the sustainability of a company's competitive advantage as the characteristics of future competition and market conditions are difficult to foresee precisely so that firms must be able to flexibly enter the market and make decisions to change in order to respond to environmental changes or developments (Kuo et al., 2017). Researchers have often linked the value of dynamic capabilities to varying degrees of environmental change and the benefits of such dynamic capabilities will be higher at high levels of environmental change, thus becoming a source of competitive advantage (Breznik \& Hisrich, 2014). This is consistent with kinds of literature 
in resource-based reviews that firms can gain competitive advantage and improve company performance in the short term if they have valuable and scarce resources.

With these dynamic capabilities, companies have the opportunity and opportunity to learn every change in their internal and external environments so that new knowledge and ideas are instantly exploited by the company quickly resulting in the competitive advantage that cannot be duplicated by other companies (Salunke, Weerawardena, \& McColl-kennedy, 2011). Therefore, with this high dynamic capabilities companies have the ability to create and utilize their resources to achieve competitive advantage in changing environmental conditions and increase their market value (Tseng \& Lee, 2014). Based on the reference, the hypothesis 2 of this research is as follows:

$\mathrm{H}_{2}$ Dynamic capabilities have the positive and significant impact on the competitive advantage

\section{The Influence of Innovation on the Competitive Advantage}

High competition intensity and environmental uncertainty make product and process innovation an important component of the company to achieve competitive advantage and improve the performance of the company because the company is able to create barriers to entry of new competitors, maintain market leader position, open new distribution networks and gain new customers for improving position in the market through a more efficient production process (Kafetzopoulos \& Gkana, 2015). The company's innovation in product, process and administrative will improve the company's performance through productivity, waiting time, quality, flexibility so that it will improve the brand position in the market and customer relationship and will also be an effective marketing tool that impacts the company's financial performance (Migdadi et al., 2017).

Innovation can be a major differentiator of a company with a competitor and a market leader because a company that fails in innovation will operate at the risk of being overtaken by a competitor, losing major employees and producing in an inefficient way (An, Deng, Chao, \& Bai, 2014). Furthermore, Baldwin and Von in An et al. (2014) explain that innovation can describe three perspectives in the company, namely: 1) High innovation will help companies to find opportunities that exist today or in the future. 2) innovation is not only limited to designing new products that will be sold to consumers or designing new production processes, but also focus on existing business processes and practices to improve enterprise efficiency, find new customers, reduce waste, and increase profits. 3) Consumers view innovation as a value-added company. Based on the reference, the hypothesis 3 of this research is as follows:

$\mathrm{H}_{3}$ Innovation has the positive and significant impact on the competitive advantage

\section{The Influence of TQM on Innovation}

TQM is a management system that can create and develop the corporate organizational culture so that it is faster, has a more systematic method to innovate products and processes by introducing and developing new products, having the high competitiveness and having high-value products (Kafetzopoulos \& Gkana, 2015). According to Deming, TQM practices will improve innovation performance by means of companies having a system that should be able to bring new ideas and companies running with continuous improvement (Sadikoglu \& Zehir, 2010). Likewise with the support of the management that encourages the emergence of new products in accordance with the needs of consumers will increase employee participation in the innovation process.

Nevertheless, the influence of TQM's application to innovation in various studies has been a debate to date. Prajogo and Sohal, and Slater and Narver in Diana, Mirela, \& Sorin (2016) explain that there are two views related to TQM's influence on innovation: TQM has a positive effect on innovation and others say that TQM is a barrier to innovation. The first view that TQM affects innovation is because it can shape systems and cultures that provide a suitable environment for companies to innovate. While the second opinion that states that TQM could be a barrier of innovation because the company focuses on methods that have been made before and the company 
tends to offer goods in accordance with the wishes of consumers. Based on the reference, the hypothesis 4 of this research is as follows:

$\mathrm{H}_{4}$ TQM has a positive and significant effect on innovation

\section{The Influence of Dynamic Capabilities on Innovation}

Teecein Ren, Yu, \& Zhu (2016) explains that companies that have dynamic capabilities will have three important components, namely, get opportunities, increase opportunities and pray threats and changes that occur within the company. To be able to create and enlarge these opportunities the company must have the resources that can to reshape existing company assets and processes so as to produce competitive advantage through the company's unique and growing capabilities all the time so as to achieve the ability to innovate that makes the dependency of the other party higher and improve the company's position in the industry (Jiao, Alon, \& Cui, 2011).

Innovation is a reflection of quality, efficiency, flexibility, and flexibility and helps dominant companies in the industry while dynamic capabilities demonstrate the company's ability to adapt to environmental changes so that innovation in such environmental change will support the company's ability to have dynamic capabilities (Jiao et al., 2011). By enhancing the company's capability in this dynamic capability, the company will be able to improve company performance and innovation (Kuo et al., 2017). Based on the reference, the hypothesis 5 of this study is as follows:

$\mathrm{H}_{5}$ Dynamic capabilities have a positive and significant effect on innovation

\section{Innovation as a Mediation Effect of TQM and dynamic capabilities on the Competitive advantage}

Innovation is one of the important topics studied in the study of management science because it has a direct influence on company performance. Several previous studies have seen much of the influence of TQM, dynamic capabilities and innovation on the excellence of the company and this research tries to test innovation as the mediation of the relationship between TQM and dynamic capabilities with the company's competitive advantage. This model is considered because the influence of TQM and dynamic capabilities on the competitive advantage is debatable as discussed by Projogo and Sohal in 2006 (Kafetzopoulos \& Gkana, 2015). There are some researchers who argue that TQM improves innovation and some say otherwise. Based on the reference, the hypothesis 6 of this research is as follows:

$\mathrm{H}_{6}$ Innovation mediates the effects of dynamic capabilities and TQM on the competitive advantage

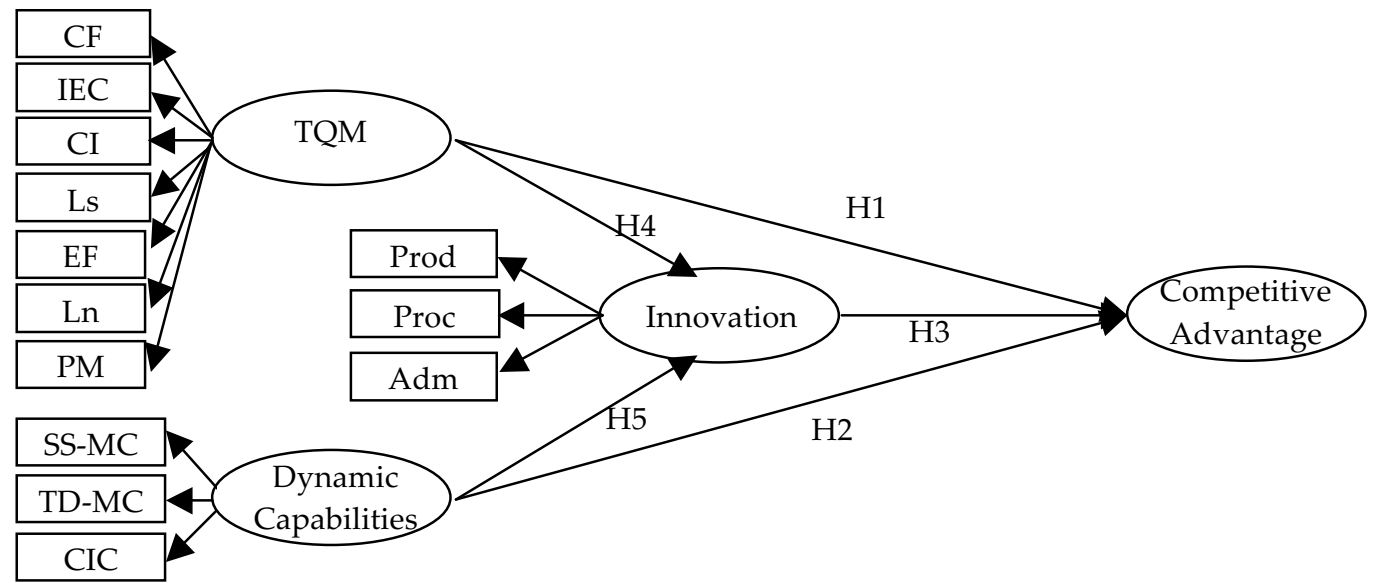

Figure 1 Research model: TQM, dynamic capabilities, innovation and competitive advantage

Figure 1 shows that TQM, dynamic capabilities, and innovation have an immediate effect on the organization's competitive advantage, as well as TQM and dynamic capabilities have a direct effect on innovation. This research model also shows that innovation mediates the influence of TQM and dynamic capabilities on the competitive advantage. TQM consists of customer focus, internal/external 
cooperation, continuous improvement, leadership, employee fulfillment, learning, and process management, while dynamic capabilities consist of strategic sense-making capacity, timely decisionmaking capacity, and change implementation capacity, while innovation consists of product innovation, process innovation, and administration innovation.

\section{Methods}

The type of this research is causative research by using survey method, that is collecting data by using questionnaires or interviews Population in this research are all faculty leadership and college faculty equivalent exist in Padang. The sample selection uses non-probability sampling, i.e. each member of the population does not have the same opportunity to be selected as a sample. The sample size for the use of multiple regression based on the rule of thumb suggested by Hair, Black, Babin, and Anderson (2010) between 50 - 100. Test the research instrument using validity test and reliability test.

The TQM definition in this study uses the opinion of Flynn et al. (1994), an integrated approach to obtaining and maintaining high-quality output, focusing on maintenance, continuous improvement, and prevention of failures at all levels and functions of the organization, in order to meet or exceed consumer expectations. TQM is measured using 7 constructs compiled by Grandzol and Gershon (1998), customer focus, internal/external cooperation, continuous improvement, leadership, employee fulfillment, learning and process management. Each question item uses a five-point Likert scale ( $1=$ strongly disagree to $5=$ strongly agree).

The definition of dynamic capabilities in this research uses Li and Liu's (2012) opinion, which is the company's potential to systematically solve problems by analyzing opportunities and threats, to make timely decisions, and to execute strategic decisions and changes efficiently to ensure correct direction. There are three constructs for measuring these dynamic capabilities: strategic sense-making capacity, timely decision-making, and change implementation capacity. Each question item uses a five-point Likert scale ( $1=$ strongly disagree to $5=$ strongly agree $)$.

The definition of innovation in this study uses Bon and Mustafa (2013), which are efforts to generate, use, mix and exploit the novelty of economic and social added value; renew and develop products, services and markets; developing production processes; and strengthen the new management system, both in the form of process and output. There are three constructs for measuring corporate invasions: product innovation, process innovation, and administrative innovation. Each question item uses a five-point Likert scale ( $1=$ strongly disagree to $5=$ strongly agree $)$.

The definition of competitive advantage in this study uses Kafetzopoulos \& Gkana (2015), i.e. the position of the company in its industry that makes the competitors unable to mimic the strategy it uses to achieve success and the company can benefit continuously from the strategy. There are five statement items to measure the company's competitive advantage, namely quality, price, delivery, flexibility and speed of introducing new products.

The data analysis method uses hierarchical multiple regression analysis by fulfilling the classical assumption test preference. The study used a three-step procedure suggested by Baron and Kenny (1986) to examine the effect of innovation mediation between total quality management and dynamic capabilities with the competitive advantage. The test of mediation effect is done by testing the direct influence of the independent variable to the mediation variable, the independent variable to the dependent variable, and the mediation variable to the dependent variable.

\section{Results and Discussion}

This research succeeded in collecting 50 majors that fill the questionnaires from all majors or college courses in the city of Padang. Based on data from 50 samples that returned the questionnaire that has been distributed, the authors get an idea of the characteristics of the sample. The data that the authors obtain about the characteristics of the sample can be seen in Table 1. 
Based on Table 1, it can be seen that of the 90 study programs collected data, 24 courses or 48 percent have a lecturer of fewer than 20 people, 16 courses or 32 percent have a lecturer amount between 20-30 people and 10 courses or 20 percent has more than 30 lecturers. Based on the number of students it can be seen that from 40 study programs collected data, 11 courses or 22 percent have less than 300 students, 9 courses or $18 \%$ have students between $300-400$ people and 30 courses or 60 percent has a student population of more than 400 people. Based on the accreditation, it can be seen that from 50 study programs collected data, 22 courses or 44 percent have a value of accreditation A, 27 courses or 54 percent have B accreditation and 1 study program or 2 percent have accreditation value C. Based on quality control, it can be seen that out of the 50 study programs collected, 39 study programs or 78 percent have internal control, 4 courses or 8 percent have ISO, 1 study program or 2 percent have other control, and 6 courses or 12 percent have two or more Quality control tools.

Table 1 Profile of Respondents

\begin{tabular}{lcc}
\hline \multicolumn{1}{c}{ Factor } & Frequency & Percentage \\
\hline Number of Lecturers & & \\
\hline$<20$ & 24 & 48 \\
\hline $20-30$ & 16 & 32 \\
\hline$>30$ & 10 & 20 \\
\hline Number of Students & & \\
\hline$<300$ & 11 & 22 \\
\hline $300-400$ & 9 & 18 \\
\hline$>400$ & 30 & 60 \\
\hline Accreditation & & \\
\hline A & 22 & 44 \\
\hline B & 27 & 54 \\
\hline C & 1 & 2 \\
\hline Quality Control & & 78 \\
\hline Internal Control & 39 & 8 \\
\hline ISO & 41 & 2 \\
\hline Other & 2 & 12 \\
\hline 2 controls or more & 6 & \\
\hline
\end{tabular}

This study used hierarchical multiple regression analysis to test all hypotheses. Model 1 shows the effect of total quality management on dynamic capabilities to test hypothesis 2 . Model 2 shows the influence of total quality management on the performance of the organization to test hypothesis 1 . Model 3 shows the effect of dynamic capabilities on organizational performance by including total quality management in the regression equation to test the hypothesis 3 . The results of data processing can be seen in Table 2 .

Hypothesis 1 states that total quality management affects the competitive advantage. The equation in model 3 based on Table 4.11 shows that hypothesis 1 is not supported ( $\beta=0.087$ and $p>0.05$ ). This equation shows that the increase of TQM variable one unit, then the performance of the organization will increase by 0.087 assuming other independent variables remains. This research did not succeed to prove that total quality management has a positive and significant impact on the competitive advantage.

Hypothesis 2 states that dynamic capabilities have a positive effect on the competitive advantage. The equation in model 3 based on Table 4.11 shows that hypothesis 2 is supported ( $\beta=0.477$ and $p$ $<0.05)$. This equation shows that the increase of dynamic capabilities variable one unit, then the competitive advantage will increase by 0.477 assuming other independent variables remain. This research has proved the effect of dynamic capabilities to competitive advantage. 
Table 2 Results of hypotheses test

\begin{tabular}{|c|c|c|c|c|c|c|}
\hline \multirow{3}{*}{$\begin{array}{c}\text { Independent } \\
\text { Variable }\end{array}$} & \multirow{2}{*}{\multicolumn{2}{|c|}{$\frac{\text { Model } 1}{\text { Dependent: INO }}$}} & \multirow{2}{*}{\multicolumn{2}{|c|}{$\frac{\text { Model } 2}{\text { Dependent: CA }}$}} & \multicolumn{2}{|c|}{ Model 3} \\
\hline & & & & & Depend & t: CA \\
\hline & $\beta$ & $t$ & $\beta$ & $t$ & $\beta$ & $t$ \\
\hline TQM & 0.331 & 1.473 & 0.202 & 0.961 & 0.087 & 0.432 \\
\hline DC & 0.377 & 1.896 & $0.607^{* * *}$ & 3.271 & $0.477^{* *}$ & 2.636 \\
\hline INO & & & & & $0.347^{* * *}$ & 2.711 \\
\hline Adj $R^{2}$ & \multicolumn{2}{|c|}{0.227} & \multicolumn{2}{|c|}{0.341} & \multicolumn{2}{|c|}{0.420} \\
\hline $\mathrm{F}$ & \multicolumn{2}{|c|}{$8.200^{* * *}$} & \multicolumn{2}{|c|}{$13.702^{* * *}$} & \multicolumn{2}{|c|}{$12.818^{* * *}$} \\
\hline \multicolumn{7}{|c|}{$* * *=\mathrm{P}<0,01,{ }^{* *}=\mathrm{P}<0,05,{ }^{*}=\mathrm{P}<0,1$} \\
\hline
\end{tabular}

Based on Table 2 can be determined the regression equation of three models above, namely:

1. $\mathrm{INO}=0.796+0.331 \mathrm{TQM}+0.377 \mathrm{DC}$ .. Model 1

2. $\mathrm{CA}=0.649+0.202 \mathrm{TQM}+0.607 \mathrm{DC}$ Model 2

3. $\mathrm{CA}=0.373+0.087 \mathrm{TQM}+0.477 \mathrm{DC}+0.347 \mathrm{INO}$ Model 3

Hypothesis 3 states that innovation has a positive effect on the competitive advantage. The equation in model 3 based on Table 4.11 shows that hypothesis 3 is supported $(\beta=0.347$ and $p<0.01)$. This equation shows that the improvement of one unit innovation variables, then the competitive advantage will increase by 0.347 assuming other independent variables remain. This research has proven the effect of innovation on the competitive advantage.

Hypothesis 4 states that total quality management has a positive effect on innovation. The equation in model 1 based on Table 4.11 shows that hypothesis 1 is not supported $(\beta=0.331$ and $p>$ $0.05)$. This equation shows that the increase of total quality management variables one unit, then the innovation will experience an increase of 0.341 with the assumption of other free variables remain. This study did not succeed in proving the effect of total quality management on innovation.

Hypothesis 5 states that dynamic capabilities have a positive effect on innovation. The equation in model 1 based on Table 4.11 shows that hypothesis 5 is not supported ( $\beta=0.377$ and $p>0.05)$. This equation shows that the increase of dynamic capabilities variable one unit, then the innovation will increase by 0.377 with the assumption of other independent variables remain. This study did not succeed in proving the effect of dynamic capabilities on innovation.

Hypothesis 6 states that innovation as mediation influences total quality management and dynamic capabilities to competitive advantage. This research has proven the effect of innovation on the competitive advantage significantly so that it can be continued to test the effect of mediation. Model 1 shows that total quality management and dynamic capabilities have no direct effect on innovation. Therefore, this study does not succeed in proving the innovation mediates the effect of Total Quality Management and dynamic capabilities on the competitive advantage.

\section{Conclusions}

Hypothesis 1 states that total quality management affects the competitive advantage. This research did not succeed to prove that total quality management has a positive and significant impact on the competitive advantage. The results of this study indicate that the increase of TQM variable one unit, then the competitive advantage will increase by 0.087 assuming other independent variables remain.

Deming in Shenawy et al., (2007) and Kafetzopoulos \& Gkana (2015) explained that the application of total quality management can develop and maintain the competitive advantage by increasing efficiency through cost reduction and increasing consumer satisfaction. This research is not in line with the research of $\mathrm{Wu}$ (2015) which states the improvement of quality management practices will increase the company's competitive advantage. 
Hypothesis 2 states that dynamic capabilities have a positive effect on the competitive advantage. The results of this study indicate that the increase of dynamic capabilities variable one unit, then the competitive advantage will increase by 0.477 with the assumption of other free variables remain. This research proves that dynamic capabilities influence to competitive advantage.

Organizations that have dynamic capabilities have competitive advantages that are difficult to imitate by other organizations because they have the ability to adapt to environmental changes. With these dynamic capabilities, the company has the opportunity and opportunity to learn every change in their internal and external environment so that it becomes new knowledge and idea and directly utilized on improving the competitive advantage. Tseng \& Lee (2014) show study high dynamic capabilities will enable organizations to create and utilize their resources to achieve competitive advantage in ever-changing environmental conditions and increase their market value.

Hypothesis 3 states that innovation has an effect on the competitive advantage. This research has proved the influence of innovation influence to competitive advantage. The results of this study indicate that the increase of innovation variables one unit, then competitive advantage will experience an increase of 0.347 with the assumption of other free variables remain. This research proves that innovation has an effect on the competitive advantage.

Company innovation in product, process and administrative will improve company performance through productivity, waiting time, quality, flexibility so that will improve the brand position in market and relation with customer and at the same time become effective marketing tool so that impact to company financial performance (Migdadi et al., 2017). Innovation can be a major differentiator of a company with a competitor and a market leader because a company that fails in innovation will operate at the risk of being defeated by a competitor, losing major employees and producing in an inefficient way (An et al., 2014).

Hypothesis 4 states that Total Quality Management has a positive effect on innovation. The results of this study indicate that the increase of total quality management variables one unit, then the innovation will experience an increase of 0.341 with the assumption of other free variables remain. This study did not succeed in proving the effect of total quality management on innovation.

The influence of total quality management on innovation in various studies has been a debate to date. Prajogo and Sohal, and Slater and Narver in Diana et al., (2016) describe that total quality management positively affecting innovation but can also hamper innovation. Total Quality Management enhances innovation because it can shape systems and cultures that provide a suitable environment for companies to innovate. Total Quality Management may be a barrier to innovation because companies focus on products and methods that have been made before.

Hypothesis 5 states that dynamic capabilities have a positive effect on innovation. The results of this study indicate that the increase of dynamic capabilities variable one unit, then the innovation will experience an increase of 0.377 with the assumption of other free variables remain. This study did not succeed in proving the effect of dynamic capabilities on innovation.

Companies that have high dynamic capabilities are expected to have the ability to innovate. Nevertheless, this condition must be supported by opportunities to gain opportunities, increase opportunities and pray the threats and changes that occur within the company. To be able to create and enlarge these opportunities companies must have resources that can reshape existing company assets and processes. This research is inconsistent with research conducted by Kuo et al., (2017) which states that dynamic capabilities improve corporate performance and innovation company.

Hypothesis 6 states that innovation as mediation influences total quality management and dynamic capabilities to competitive advantage. This research has proven the effect of innovation on the competitive advantage significantly so that it can be continued to test the effect of mediation. Model 1 shows that total quality management and dynamic capabilities have no direct effect on 
innovation. Therefore, this study does not succeed in proving the innovation mediates the effect of Total Quality Management and dynamic capabilities on the competitive advantage.

\section{References}

Al-Hakim, L. A. Y., \& Hassan, S. (2013). Knowledge management strategies, innovation, and An empirical study of the Iraqi MTS. Journal of Advances in Management Research, 10(1), 58-71. https://doi.org/10.1108/09727981311327767

An, X., Deng, H., Chao, L., \& Bai, W. (2014). Knowledge management in supporting collaborative innovation community capacity building. Journal of Knowledge Management, 18(3), 574-590. https://doi.org/10.1108/JKM-10-2013-0413

Ashrafi, R., \& Mueller, J. (2015). Delineating IT resources and capabilities obtain competitive advantage and improve firm performance. Information Systems Management, 32(1), 15-38. https://doi.org/10.1080/10580530.2015.983016

Baron, R. M., \& Kenny, D. a. (1986). The moderator-mediator variable distinction in social the moderator-mediator variable distinction in social psychological research: Conceptual, strategic, and statistical considerations. Journal of Personality and Social Psychology, 51(6), 1173-1182. https://doi.org/10.1037/0022-3514.51.6.1173

Bon, A. T., \& Mustafa, E. M. A. (2013). Impact of total quality management on innovation in service organizations : Literature review and new conceptual framework. Procedia Engineering, 53, 516529. https://doi.org/10.1016/j.proeng.2013.02.067

Breznik, L., \& Hisrich, R. D. (2014). Dynamic capabilities vs . innovation capability: Are they related? Journal of Small Business and Enterprise Development, 21(3), 368-384. https://doi.org/10.1108/JSBED-02-2014-0018

Caniato, F., Caridi, M., \& Moretto, A. (2013). Dynamic capabilities for fashion-luxury supply chain innovation. International Journal of Retail \& Distribution Management, 41(11), 940-960. https://doi.org/10.1108/IJRDM-01-2013-0009

Cheng, C. C. J., \& Chen, J. (2013). Breakthrough innovation: The roles of dynamic innovation capabilities and open innovation activities. Journal of Business $\mathcal{E}$ Industrial Marketing, 28(5), 444454. https://doi.org/10.1108/08858621311330281

Diana, C., Mirela, I., \& Sorin, M. (2016). Approaches on the relationship between competitive strategies and organizational performance through the total quality management (TQM ). In 7 th International Multidisciplinary Symposium: Sustainable Development Through Quality and Innovation in Engineering and Research, 328-334.

Flynn, B. B. (1994). The relationship between quality management practices, infrastructure and fast product innovation. Benchmarking for Quality Management \& Technology, 1(1), 48-64.

Haan, H. H. de. (2015). Competitive advantage, what does it really mean in the context of public higher education institutions? International Journal of Educational Management, 29(1), 44-61.

Hair, J. F., Black, W. C., Babin, B. J., \& Anderson, R. E. (2010). Multivariate Data Analysis. 7th ed. New York: Pearson.

Heizer, J., Render, B., \& Munson, C. (2017). Operations Management: Sustainability and Supply Chain Management. Twelfth Ed. United States of America: Pearson.

Jiao, H., Alon, I., \& Cui, Y. (2011). Environmental dynamism, innovation, and dynamic capabilities: the case of China. Journal of Enterprising Communities: People and Places in the Global Economy, 5(2), 131-144. https://doi.org/10.1108/17506201111131550

Kafetzopoulos, D., \& Gkana, K. G. V. (2015). Relationship between quality management, innovation 
and competitiveness. Evidence from Greek companies. Journal of Manufacturing Technology Management, 26(8), 1177-1200.

Kuo, S., Lin, P., \& Lu, C. (2017). The effects of dynamic capabilities, service capabilities, competitive advantage, and organizational performance in container shipping. Transportation Research Part A, Part A(95), 356-371. https://doi.org/10.1016/j.tra.2016.11.015

Lee, V.-H., Leong, L., Hew, T., \& Ooi, K. (2013). Knowledge management: A key determinant in advancing technological innovation? Journal of Knowledge Management, 17(6), 848-872. https://doi.org/10.1108/JKM-08-2013-0315

Li, D. yuan, \& Liu, J. (2014). Dynamic capabilities, environmental dynamism, and competitive advantage: Evidence from China. Journal of Business Research, 67(1), 2793-2799. https://doi.org/10.1016/j.jbusres.2012.08.007

Migdadi, M. M., Zaid, M. K. A., Zaidbauedujo, M., Yousif, M., \& Al-hyari, K. (2017). An empirical examination of knowledge management processes and market orientation, innovation capability, and organisational performance: Insights from Jordan. Journal of Information $\mathcal{E}$ Knowledge Management, 16(1), 1-32. https://doi.org/10.1142/S0219649217500022

Nielsen, A. P. (2006). Understanding dynamic capabilities through knowledge management. Journal of Knowledge Management, 10(4), 59-71. https://doi.org/10.1108/13673270610679363

Ren, R., Yu, L., \& Zhu, Y. (2016). Innovation-orientation, dynamic capabilities and evolution of the informal Shanzhai firms in China: A case study. Journal of Entrepreneurship in Emerging Economies, 8(1), 45-59.

Sadikoglu, E., \& Zehir, C. (2010). Investigating the effects of innovation and employee performance on the relationship between total quality management practices and firm performance: An empirical study of Turkish firms. Int. J. of Production Economics, 127(1), 13-26. https://doi.org/10.1016/j.ijpe.2010.02.013

Salunke, S., Weerawardena, J., \& Mccoll-kennedy, J. R. (2011). Towards a model of dynamic capabilities in innovation-based competitive strategy: Insights from project-oriented service firms. Industrial Marketing Management, 40(8), 1251-1263.

https://doi.org/10.1016/j.indmarman.2011.10.009

Shenawy, E. El, Baker, T., \& Lemak, D. J. (2007). A meta-analysis of the effect of TQM on competitive advantage. International Journal of Quality \& Reliability Management, 24(5), 442-471. https://doi.org/10.1108/02656710710748349

Tseng, S., \& Lee, P. (2014). The effect of knowledge management capability and dynamic capability on organizational performance. Journal of Enterprise Information Management, 27(2), 158-179.

https://doi.org/10.1108/JEIM-05-2012-0025

Wu, Q., He, Q., \& Duan, Y. (2013). Explicating dynamic capabilities for corporate sustainability, 8(3), 255-272. https://doi.org/http://dx.doi.org/10.1108/MRR-09-2015-0216

$\mathrm{Wu}, \mathrm{S}$. J. (2015). The impact of quality culture on quality management practices and performance in Chinese manufacturing firms. International Journal of Quality \& Reliability Management, 32(8), 799814. 